\title{
A COMMENT ON FEDERAL RULES, LOCAL RULES, AND STATE RULES: UNIFORMITY, DIVERGENCE, AND EMERGING PROCEDURAL PATTERNS
}

\section{JANET NAPOLITANo $\dagger$}

Professor Subrin demonstrates that two of the essential pillars supporting the 1938 Rules were uniformity and simplicity. Just as convincingly, Professor Subrin shows that Rule 83 has injected disuniformity and complications into the procedural order. Like a computer virus of indeterminate origin, Rule 83 has created ripple effects throughout the districts, felt most keenly and unfortunately by litigants and their lawyers. Only a party who has been sent away from the clerk's office without being allowed to file a complaint on the last possible day because it was punched with two holes, not three, can fully appreciate the injustice that supposedly benign local rules can cause.

While Professor Subrin has described the infinite variety of local rules as well as the problems caused when local rules vary between state and federal practice, even in the so-called replica states, he has stopped short of prescribing what can be done to relieve the situation. As a litigator in both state and federal courts and as the chair of the local rules subcommittee of the Arizona State Bar Civil Practice and Procedure Committee, I would like to describe what we are doing in Arizona, a state that Professor Subrin has singled out for particular discussion.

All rules of civil procedure, including local rules, are given to the State Bar Givil Practice and Procedure Committee for review and comment. The committee's findings are referred to the State Bar Board of Governors and then to the Supreme Court for promulgation, with substantial alteration or outright disapproval occurring at any stage in the process. The local rule subcommittee was formed two years ago, after three or four consecutive meetings when thirty or so committee members went through packets of local rules word by word, comma by comma, without any firm direction or criteria for evaluating those rules.

The local rule subcommittee's first task was to develop the criteria

† Partner, Lewis \& Roca, Phoenix, Arizona. Member, Arizona State Bar Civil Practice and Procedure Committee; Chair, Local Rules Subcommittee. 
against which all proposed local rules would be measured. These criteria fell into two general categories: subject matter and draftsmanship.

In respect to subject matter, the first measure is whether the local rule is necessary. There is a tendency to overlegislate in the rules arena. When overlegislation takes place, the courts and the lawyers lose some desirable flexibility. To evaluate whether a rule is necessary, the subcommittee considers the stated basis for the rule. Many times, a rule is proposed in reaction to one unfortunate incident which has little or no chance of repeating itself and which could be dealt with more appropriately by the trial court on an individual basis rather than by a new local rule. The subcommittee's presumption is against new local rules, so that the proponent bears the burden of showing that a need exists.

Once it is shown that a local rule is necessary, the next measure is whether the proposed rule would conflict with a statute, federal or state rule of civil procedure or case law interpreting those rules, uniform rule, ${ }^{1}$ or other local rule. By the dictates of Rule 83 , if a proposed local rule conflicts with a rule of civil procedure, it cannot be adopted. It may, however, provoke thought as to whether the rule of procedure should be amended or clarified. The same is true of conflicts with uniform rules. If the proposed local rule conflicts with other local rules on the same subject, the subcommittee evaluates whether a need for diversity exists. One example of local rulemaking in which logistics may require diversity is rules concerning telephone arguments. While most courts in the state recognize that arguments may be made by telephone, some courts simply do not have the phone technology available to permit telephone arguments to be made. If no reason can be ascertained for having different local rules on the same subject, the subcommittee considers whether to amend the proposed local rule to conform with existing local rules or whether to suggest a uniform rule and abolish all local rules on that subject.

Having determined that a proposed local rule is necessary and does not create undue conflict, the committee proceeds to draftsmanship. The first criterion is simplicity. Rulemakers should write rules in simple, declarative sentences. All rule writers can benefit from reviewing publications such as The Elements of Style ${ }^{2}$ and Plain English for Lawyers. ${ }^{3}$ The subcommittee also checks grammar and spelling.

The subcommittee pays considerable attention to whether the proposed local rule communicates its essential message. For example, a local rule that states simply that the presiding judge has the power to

1 In Arizona, uniform rules are local rules that apply in every county.

2 W. Strunk \& E.B. White, The Elements of Style (3d ed. 1979).

${ }^{3}$ R. Wydick, Plain English for Lawyers (1985). 
set the court's hours is not very helpful to the lawyer who needs to know whether he has until 5:00 p.m. or 6:00 p.m. to make a filing. Local rules that contain references to other rules or to statutes-the "except as provided by law" problem-are particularly discouraged. The guiding presumption is that local rules are needed by lawyers for quick and definitive answers on how to do something that is fairly ministerial in nature. They are not Talmudic texts for the learned; they are road maps for the ordinary traveler. In this respect, indexing and numbering cannot be overlooked. All local rules regarding discovery, for example, should be in one place under one common sense numbering system. That way, they will appear in the same place in the local rules index, which will help guarantee that they are not overlooked.

There remains the political problem, to which Professor Subrin does no more than allude in his paper. Some courts are simply unwilling to sacrifice their rulemaking discretion to oversight by a committee for performance of the exercise described above. To the extent a judge as local rulemaker wishes to act autonomously and independently, for whatever reasons, not much can be done to prevent it. By emphasizing uniformity and simplicity as worthy goals, however, it is to be hoped that such instances are rare.

Much uniformity can be achieved if local rulemakers cooperate with one another. Professor Subrin refers in his article to the problems local rules create for lawyers who must jump from state to federal court and back again. Even in replica states like Arizona, the lawyer may have two sets of local rules governing his actions, making any notion of "replica" an illusion. In 1987, Chief Judge Richard Bilby of the United States District Court for the District of Arizona appointed a committee to ascertain whether the local rules of the district court and the superior courts of Pima and Maricopa Counties (the state's two largest trial courts) could be harmonized and made more uniform so that the life of lawyers practicing before the courts could be made easier. The committee, chaired by the Hon. Robert Broomfield, expanded its work to include amendments to the Uniform Rules of Practice as well. As the Bilby committee noted in its final report:

The tentative adoption of the rules by these three courts was not without substantial effort and discussion. It required compromise initially on the part of the members of the committee and later by the judges of the three courts, and the civil committees or working groups within them. It was a painstaking effort. The spirit of cooperation reflected the desire on everyone's part to achieve the goal of providing the uniformity necessary to aid lawyers in the practice of law 
before these Courts. ${ }^{4}$

The harmonized rules run the gamut of local rules procedural practice. Docketing format, transfer or consolidation of related civil cases, case assignment, attachments to pleadings, attorney calendar conflicts, ex parte presentations, withdrawal and substitution of counsel, discovery papers, exhibits, refiling, oral argument, and size of type are just some of the rules covered. While the committee report does not purport to be exhaustive and while all conflicts were not erased, it presents a major step in the direction of reunifying and resimplifying the rules system. It is at least a partial answer to Professor Subrin's criticism that two different local rules systems should not apply depending on whether one is at the federal courthouse or the state courthouse. The virus of unceasing and unnecessary differentiation and variation can be stopped.

I cannot close my comments without thanking Professor Subrin for focusing on local rules as a microcosm exemplifying how the procedural system has strayed from the principles of 1938. As a practitioner, I appreciated the attention being paid to an area that affects litigants and lawyers so directly. As one who enjoys thinking and reading about procedural topics, I enjoyed the thoroughness and thoughtfulness of Professor Subrin's paper. Professor Subrin has something to teach in this area and he has taught us well.

4 Report, Amendments to the Local Rules of Practice for: Superior Court of Arizona in Pima County, Superior Court of Arizona in Maricopa County, U. S. District Court for the District of Arizona, and Recommended Amendments to the Uniform Rules of Practice of the Superior Court of Arizona (Feb. 1, 1988) (on file with the University of Pennsylvania Law Review). 